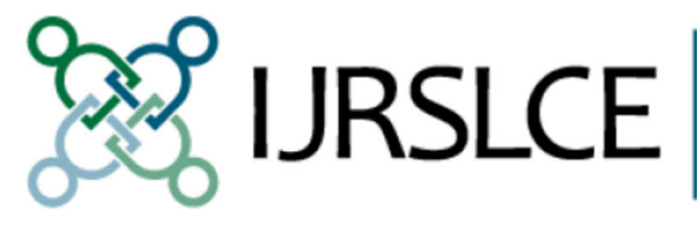

\author{
International Journal \\ for Research on \\ Service-Learning \& \\ Community Engagement
}

\title{
Moving From Thin to Thick Conceptions of Civic Engagement: Faculty Identity and Goals for Democratic Learning
}

\author{
Spoma Jovanovic \\ Kristin Moretto \\ Kathleen Edwards
}

This article was originally published at:

https://journals.sfu.ca/iarslce/index.php/journal/article/view/286/192

Recommended Citation

Jovanovic, S., Moretto, K., \& Edwards. K. (2017). Moving from thin to thick conceptions of civic engagement: Faculty identity and goals for democratic learning. International Journal of Research on Service-Learning and Community Engagement, 5(1), 25-40. 


\title{
Moving from Thin to Thick Conceptions of Civic Engagement: Faculty Identity and Goals for Democratic Learning
}

\author{
Spoma Jovanovic \\ University of North Carolina at Greensboro \\ Kristin Moretto \\ Grand Valley State University \\ Kathleen Edwards \\ University of North Carolina at Greensboro
}

\begin{abstract}
Colleges and universities continue to respond to the call for a deepening of community-engaged research and teaching that contributes tangibly to the public good. Coupled with a new generation of scholars eschewing traditional markers of academic success, the authors set out to discover what faculty members at an urban university identify as priorities for teaching and research to advance democratic engagement. They collected quantitative and qualitative data from faculty members and their community partners. The study findings suggested that while community-engaged activity continues to grow and even thrive among an increasing number of faculty members, there remain three targeted areas needing improvement in order for democratically informed scholarship to better serve the public good: (1) The need to transform "thin" student learning goals into more robust, "thick" civic learning goals; (2) increasing what now is minimal, if existent, discussion of the political opportunities for and constraints to community work; and, (3) a fuller integration of faculty interests, personal and professional, with teaching and research priorities centering on democratic engagement.
\end{abstract}

Keywords: democratic engagement, civic engagement, community engagement, faculty identity

Increasingly, urban universities recognize the vital role they play not only in educating their students, but also in contributing to the quality of life of the communities in which they are anchored (Overton, Pasque, \& Burkhardt, 2017; Perry \& Menendez, 2010). At the same time, growing numbers of faculty have "begun to reframe, restructure, and reimagine themselves in order to help prepare today's students to become stewards of a democracy desperately in need of courageous, thoughtful, informed, caring citizens" (Musil, 2012, p. 70; see also Post, Ward, Longo, \& Saltmarsh, 2016). This marked commitment to making education relevant in the public sphere is not haphazard; realigning traditional academic instruction to bolster civic engagement recognizes the crucial role of education in orienting students to self-fulfillment and, more importantly, improving communal well-being. Over the last several decades, these interests have given rise to increased community-engaged activity, such as service-learning courses, in which instruction and research are directed toward mitigating injustices, bolstering community assets, and fostering the deep tolerance that democracy requires. Yet, for all this progress, meaningful civic engagement remains an unfinished project. 
The terms civic engagement, community engagement, democratic engagement, service-learning, and participatory action research are routinely used interchangeably and have been the subject of much academic debate. For the purposes of our study, civic engagement is defined as:

working to make a difference in the civic life of ... communities and developing the combination of knowledge, skills, values and motivation to make that difference. It means promoting the quality of life in a community, through both political and non-political processes. (Erhlich, 2000, p. vi)

Situated within that broad area of scholarship, and for our study, community engagement focuses on local endeavors, while democratic engagement concentrates on self-governing activities-dialogue,

deliberation, and community building that rely on lay participation, respect for and inclusion of affected community members, and activities that address public concerns and/or public policy - as the foundation upon which academic programs are based (Della Carpini, 2004; Saltmarsh, Hartley, \& Clayton, 2009).

This study analyzed the practices and priorities of self-identified community-engaged scholars at a publicly supported state university designated by the Carnegie Foundation as a community-engaged research university in both curricular engagement and outreach and partnerships. Set within a context of shrinking budgets and a new generation of scholars eschewing traditional markers of academic success, along with expanding paradigms of teaching and research activity committed to the public good, we set out to discover what community-engaged faculty at an urban university identify as their priorities for teaching and research.

The impetus for this study hinged on a simple yet critical insight: "With community engagement unfolding as it is on campuses nationwide, our attention to the impact it can have politically, as well as socially, opens the door for greater citizen involvement in which students can easily participate" (Poulos, Hamilton, Jovanovic, \& Moretto, 2015, p. 43). In other words, for students to be civically proficient, they need to be exposed not only to social problems, but also to the democratic means by which change happens within political systems. We believe community-engaged teaching and research can comprise an important vehicle toward the development of civic competencies and democratic learning and engagement among college and university students.

We asked the following research questions: (a) What drives faculty to develop meaningful and reciprocal community engagements? (b) What do those faculty teach in the classroom to instill specified democratic goals? (c) What institutional supports could encourage greater, deeper community and democratic engagement activities for the public good? More specifically, we wanted to know what motivates faculty to adopt a community-engaged scholarly identity and how those motivations inform their goals for student civic learning. Do community-engaged faculty teach in ways that advance a strong or "thick," rather than "thin," conception of democracy (Barber, 1984)?

The political dimensions of democratic engagement are especially important to consider in light of the disappointing news that Harry Boyte and Blase Scarnati delivered in 2014. They explained that active democratic learning reaches into all domains of daily life; yet, too often, students - and faculty for that matter-focus their learning and instruction on limited, government-sponsored activities such as voting and communication with elected officials. In doing so, the rich political features of public life, including work to form civic character, influence public policy, and organize against injustices, are often left undetectable. Boyte and Scarnati continued: "At every level, educational institutions have enormous power that operates invisibly to shape identities, assumptions and ways of looking at the world" (p. 87). Therefore, our aim in this study was to make visible at least some of these features of democratic education.

In line with the growing interest across the United States in infusing democratic engagement into existing community and civic-engagement commitments, we believe that democratic engagement must transcend its oftentimes limited focus on voting and electoral politics, which are necessary but insufficient to advance democracy. A self-governing society for which higher education ought to prepare students requires much more. Principally, students need to be exposed through critical thinking and engagement to the tools, experiences, and political processes that shape society. The American Democracy Project and NASPA's Civic Learning and Democratic Engagement initiative are two such examples of projects 
pushing past the traditionally accepted but limited focus on voting and electoral politics. Similarly, law professors Erwin Chemerinsky and Howard Gillman (2017) maintained that what is necessary for democracy to thrive is "the people's ability to formulate and communicate their opinions about what decisions or policies will best advance the community's welfare" (p. 25). Toward that important end, several pedagogical interventions are crucial: critical, political discussions; meaningful work with community change agents; and co-production of research, strategic initiatives, and resource development that connects public issues with faculty expertise and interests (Stoecker, 2016).

In the following sections, we consider how faculty come to embrace civic engagement as democratic activity and, further, how that conception unfolds in their scholarly endeavors. We report on the dimensions of faculty identity central to the development of a community-engagement profile before turning to a discussion of faculty teaching goals for civic engagement and democratic learning. We then examine the community and institutional supports and barriers that make community-engagement activity both possible and sometimes difficult. This information, though reflective of faculty at only one campus, has implications for faculty elsewhere as colleges and universities host robust discussions to best determine what levels of community-engaged activity for the public good they can sustain.

\section{Democratic and Civic Engagement}

John Saltmarsh, Matt Hartley, and Patti Clayton (2009) articulated clearly in their "Democratic Engagement White Paper" that civic engagement within higher education is too often apolitical and so broadly defined that nearly any work in the community fits under its heading. The problem, they posited, is that absent a more distinct and robust definition, civic engagement may actually inhibit the challenge to work collaboratively with others to delve into more serious concerns of the community, ones that necessarily raise questions of how power is distributed, how individuals are included in decision making, and how changes in spending can affect the public good, to name only a few of the ways in which democracy is put into action. Of course, civic engagement does not have to be devoid of democratic underpinnings, but too often it is.

For scholars intent on advancing democratic values as they work with students to be active stewards of the community's welfare, integrating democratic engagement into teaching and research is not simply about asking students to invest a set number of hours of work within the community. Instead, "community partnerships in a democratic-centered framework of engagement have an explicit and intentional democratic dimension framed as inclusive, collaborative, and problem-oriented work" (Saltmarsh et al., 2009, p. 9). From the design of the class or research project, democratic engagement requires that scholars recognize the important contributions of community members embroiled in public issues to the design and implementation of programs that can lead to needed changes advancing society's democratic mission.

To advance civic learning as democratic engagement, many instructional pieces are necessary beyond simply pairing disciplinary content with like community programs. For instance, for students and scholars advocating for affordable housing, the history of the community's commitment as well as the local political climate's embrace of or resistance to subsidized housing represent crucial information in the teaching and/or research materials. Turning to local housing advocates to absorb the impact of their past successes and failures exposes students and scholars to the legacy of democratic engagement upon which newer programs and teaching can be built. Such a pairing of curricular content - often broad, theoretical, and somewhat abstract - with the very specific, place-based, and experience-oriented content of community partnerships reveals the multiple and complex layers of democratic engagement, making more evident how daily life is linked to politics. This strategy was one valued by civil rights leaders of the 1960s and continues to be valued Black Lives Matter (BLM) leaders of today (for instance). Patrisse Khan-Cullors, one of the three originators of \#BlackLivesMatters, explains this process of local action in response to broad systems at work: "The local is where the work is, you know? If we're looking at just the national, it's pretty devastating. But if you zoom in to cities, to towns, to rural areas, people are fighting back, and people are winning" (as cited in Wang, 2017, para. 23). 


\section{Methods}

This study was a mixed-methods research project relying on both quantitative and qualitative data analyzed by a research team made up of a tenured faculty member, a professional administrator, and a doctoral-seeking graduate student all involved with community-engaged scholarly activities. Our methods comprised a sequential collection strategy that gathered information from closed and open-ended questioning (Creswell, 2003). Between February and May 2013, we collected diverse types of data, first via a broad survey and then through faculty focus groups (Creswell, 2003). We also consulted archival data of small-group discussions with community partners.

\section{Procedure}

We began with a 20 -item survey sent by email to 203 faculty members whom we had previously identified as service-learning instructors or community-engaged scholars. To increase participation, we sent two follow-up reminders to the survey recipients during the six weeks that the survey was open. In total, 76 people started the survey and 40 completed it, for a $20 \%$ response rate.

The survey included closed questions designed to collect demographic data (e.g., age, gender, years at the university) and open-ended questions that probed for details regarding: (a) participants' identities as community-engaged scholars, (b) goals for student learning, and (c) the support for their community partnerships. Example questions included:

- "Please explain the nature of your community-engagement work and what brought you to it."

- "What challenges have you faced as a community-engaged scholar?"

- "What specific civic learning and/or democratic engagement goals do you have for your teaching?"

- "How would you characterize the support for community engagement that you get from your department, unit and the University?"

After the survey data had been collected, we organized two focus groups-involving 12 people total from among the survey respondents - to collect stories of success, satisfaction, difficulties, and suggested changes for developing civic learning opportunities and enhancing institutional services. We held both focus groups during the same week, each lasting 90 minutes. As an incentive for participation, we offered a teaching- or research-related item from the campus bookstore to all participating faculty. After the sessions were audio-taped and transcribed, the entire research team reviewed the transcriptions.

In addition to the surveys and focus groups, we reviewed data collected at the university's annual year-end celebration of university-community projects. This event featured community-partner roundtable discussions, in which 20 faculty and staff, along with 55 community members, considered how to best foster civic ethos, literacy, inquiry, and action - pillars of the core competencies in civic engagement (National Task Force, 2012). The research team analyzed the collected and collated discussion comments from the celebration for thematic content. We used these data as a secondary source, thereby triangulating our data to offer support for our themes from multiple sources and perspectives (Hatch, 2002).

We developed our codes from an analysis of the open-ended survey data and then organized those codes into larger themes (Boyatzis, 1998; Creswell, 2007). We used these themes to analyze the focus group discussions and community partner round table notes, with new themes added as they emerged from the data (Creswell, 2007).

\section{Survey and Focus Group Participants}

Of the 40 faculty participants who completed the initial survey, $59 \%$ identified as tenured, $18 \%$ as on the tenure track, and $23 \%$ as non-tenure-track or graduate students. Of the 12 faculty members in the two focus groups, $67 \%$ were tenured, $25 \%$ were on the tenure track, and $8 \%$ were non-tenure-track employees.

Females were overrepresented among the survey respondents at $63 \%$, compared to the institution's general faculty population of $46 \%$ women (Collaborative on Academic Careers in Higher Education, 2012). However, regarding ethnic identity, study participants mirrored the institutional profile, 
with $85 \%$ identifying as White/Caucasian, $8 \%$ as Asian/Asian American, 5\% as African American, and $3 \%$ indicating their ethnicity as "Other." Finally, the ages of the survey participants were approximately the same as the composite for the university, with $8 \%$ of study participants under the age of $35,16 \%$ between 35 and 44, 63\% between 45 and 64, and 13\% 65 or older.

Further, respondents' average years of employment at the university was 14.8 years, with nearly half, or $48 \%$, employed for seven to 19 years, another $25 \%$ employed more than 20 years, and $27 \%$ at the institution for fewer than six years.

Notably, we did not query survey respondents about their academic disciplines in order to preserve anonymity. However, we distributed the survey to community-engaged faculty at the institution, with representation from each of the six colleges and schools included. Further, the disciplinary data from focus-group participants revealed representation from all but one of the colleges, the business school being the exception. Focus-group representation was strongest in the social sciences and arts.

Finally, because promotion and tenure guidelines were revised in 2008 to recognize communitybased teaching, research, and service, we queried survey participants about how they situated their community-engagement activity. Most were active in all areas: $80 \%$ reported participating in communitybased service, $73 \%$ indicated they used community-engaged teaching methods, and $68 \%$ reported involvement with community-based research.

\section{Faculty Identity and Motivations}

Faculty perform the core work of teaching for a strong democracy by preparing students for active participation in public work (Snyder-Hall, 2012). This work is embedded in the tradition of higher education and supported now in nationwide efforts by Campus Compact, the American Association of Colleges and Universities, and others. Still, as critical scholar Henry Giroux (2017) explained, that vision of higher education and the role of faculty in it are under an unprecedented assault. The mandate to produce graduates as workers - not citizens - has gained momentum as economic insecurities reshape federal, state, and local priorities. Questions surrounding faculty workload are the most recent accountability demands being dispatched by suspicious lawmakers and others who wonder what faculty do with their time if they only teach a few classes a week (June, 2014). Technology, too, is being held up as a way to increase faculty productivity, often without adequate data or support to determine its best use. The rise of non-tenure-track instructors sends another message, namely that the academic freedom once heralded as a hallmark of higher education is rapidly losing favor as a measure of distinction. Where, then, is the place for the propagation of higher education as "the citadel of democratic learning" (Giroux, 2012, p. 124)? Will faculty who are committed to civic engagement and democratic learning be rewarded or retained in an environment where student success is measured foremost by job placements after graduation? As Claire Snyder-Hall (2012) of the Kettering Foundation explained in her study of faculty aspirations, "faculty efforts to explicitly prepare students for citizenship, to engage in public scholarship, or to partner with communities to share problems are seen as marginal" (p. 35) to the mission of the university, which increasingly views itself and operates as a business. Yet, at least some faculty members persist in advancing democratic learning, a career trajectory they attribute primarily to childhood influences or alignment with research interests surrounding contemporary social issues. What, then, propels faculty toward community-engaged teaching that can foster democratic learning?

\section{Influence of Family on Faculty Propensity for Civics}

Many faculty in our study reported being influenced to pursue public service through hands-on community-engagement activities with their family or as part of their early education. One faculty member explained, "I think a lot of it has to do with how I was raised.... I did lots ... of service projects at school but I think probably more than anything it's my background." In the process of doing service at a young age, faculty reported acquiring a keen knowledge of critical social issues. One participant articulated what others reported: "What brought me to this work was the glaring need for services and supports for [vulnerable] population groups and the opportunities this presented for my students." 
Thus, many of the faculty members in our study viewed community engagement in academic life as a natural outflow of their identity. For instance, one senior professor explained that she could not distinguish community engagement from her professional activity:

I don't know that I can separate the two. It would just be impossible for me to separate the two.... and as for me as a scholar, I wouldn't be doing research unless it was making a direct impact on the community.

Blending the demands and requirements of their academic jobs with deeply held personal values to make the world better encouraged a portion of the faculty to embrace community engagement and civic learning as central to their teaching and research duties.

\section{Community Engagement as a Professional Track}

Professional interests, not family background, motivated other faculty to join scholars pursuing community engagement within their disciplines as a distinct professional track. One intercultural communication faculty member, for example, began reaching out to the local immigrant community to gain an understanding of the concrete challenges refugees face. That act, in turn, led to interest in civic engagement, with support offered by other community- engaged colleagues. Another faculty member reported being exposed to urban education earlier in his professional career as a high school teacher. When he entered the ranks of higher education, he said he was attracted to his current department because of its approach to teaching from a social-justice perspective. For yet another faculty member, a previous job with a nonprofit agency serving refugees was the impetus and focus for her current university teaching position. Finally, another faculty member explained that in the course of making a documentary film, he discovered unknown political challenges to a local business that influenced a shift in his work toward advocacy efforts. The film would later be used to support new legislation affecting the community members profiled in the film.

Faculty members also noted that they found their way to civic engagement and democratic learning through peers and allies who explained how teaching, research, and service could be integrated. One said:

I came to [civic engagement] through a wonderful mentor ... but also out of a desire to be part of real change, and see it in real time, and provide students with an opportunity to experience that as well before they leave college.

Another faculty participant was influenced in graduate school to conduct research that could have a tangible impact.

Some faculty reported gravitating toward civic or community engagement as a way to improve their teaching and research. Many faculty members reported that service-learning energized their courses and helped students engage more thoughtfully with the reading material. However, for at least one faculty member, his expertise was the basis of his recruitment into community engagement. He said he was sought out "by a dean and community partner looking for a faculty member" to work with on a community-based project.

In these varied cases, faculty members were not typically initiators of campus-community partnerships, but they were receptive to the opportunities made available to them.

\section{Translating Civic Engagement into Learning Outcomes}

In higher education today, a contingent of faculty at many, if not most, colleges and universities are embracing the need to teach students twin goals in their courses: advancement of disciplinary knowledge and development of civic capacities. To get there, service-learning courses are often used, those credit-bearing, academically situated experiences that include an organized service activity to address community needs (Bringle \& Hatcher, 1995). Other educational experiences that may likewise accomplish similar goals exist in courses featuring community-based research, engaged scholarship, and select internships and practicums. Common to all of these is a focus on systematic inquiry, often through 
sustained involvement in a community project, integration of community experiences with academic theories and/or concepts, and reflective practices, both oral and written.

Through such courses and experiences, the development of civic capacities is presumed to take place in the community Faculty members may deliberately provide instruction and practice in designated civic skills or they may rely on the community experience to provide those skills by way of on-the-ground instruction. Our research revealed that much work remains to be done among faculty who have differing conceptions of civic literacy and democratic engagement (Adler \& Goggin, 2005).

For educator Bill Ayers (2004), democratic engagement requires that students locate themselves in the broader community or society, identify the barriers to humanity, and then join with others in collective action to address lingering injustices. His call, echoing the educational philosophies of John Dewey and Paulo Freire, seeks liberation through the attainment of truth and knowledge that can build human community and reduce oppression where it continues to operate as exploitation, unfairness, and lack of compassion. That approach to education, however, defies an orientation toward rubrics intended to provide a direct path from instruction to student learning outcomes. Instead, the process of teaching toward freedom, Ayers says, is messy, contingent, and in response to student needs that cannot be identified in advance:

It requires a continual identification of what is to be done, a constant process of unfolding and moving forward ... It can be halting and it can be slow, but it can also become an achievement and surprise us with the suddenness and power of change. (p. 81)

To reach students where they are and move them toward a closer connection to community matters, Ayers echoed bell hooks (2003), who urged educators to love their students so that the students in turn can experience the power of self-love, which will propel them to take action in the world. As such, communication and relating well with students are central to the possibilities of this kind of teaching (Gay, 2015). Other scholars, notably John Gastil and Peter Levine (2005), argued that civic engagement requires that educators teach students specific skills to help them navigate the complexities of society. Through their focus on processes of deliberative democracy, these authors offered advice and suggestions for enhancing democratic engagement by improving critical thinking, enhancing meaningful participation in civic matters, and generating informed decision making.

Among these multiple and varied skills and attitudes - connecting the individual to the collective, naming and addressing social injustices, self-love, communicating and relating well with others, critical thinking - an anchor point for deliberative democracy is dialogue, that collaborative enterprise that asks participants to be authentic as they listen carefully to others. Further, dialogue is the means by which people imagine new possibilities together and consider that their previously held beliefs or views might need to change (Anderson, Baxter, \& Cissna, 2004). Longitudinal research conducted from 2005 to 2009, involving more than 1,000 high school students in the midwestern United States, revealed that students in classes that engaged in discussion about controversial political issues more than $20 \%$ of the time were more likely to continue discussions, vote, and be civically engaged after graduation (Hess \& McAvoy, 2015). Other research at the college level suggests that when students participate in meaningful dialogue in higher education, they likewise sustain the positive benefits after graduation (Diaz \& Perrault, 2010).

Recognizing that students live in an increasingly diverse and connected world, much attention in the context of advancing democratic education has been devoted to improving students' multicultural awareness. For Boyle-Baise (2002), this means that instruction and service-learning opportunities must be "antiracist, inclusive, critical, and socially just" (p. 16). Multicultural awareness recognizes that overlapping systems of privilege operate in the United States and globally to disadvantage women, people with varied abilities, racial and ethnic minorities, the LGBTQI community, and targeted religious groups (Duerringer, 2013). Rather than aiming for color-blindness or neutrality in developing civic capacities, a multicultural approach honors the stories and lived experiences of people as the starting point from which to learn about one's civic responsibilities (Cortes, 2010). 


\section{Civic Learning and Democratic Engagement Goals for Students}

In surveys and focus groups, we asked community-engaged faculty members about their civic learning and democratic engagement goals for students. We also accessed notes from community partners, in roundtable discussions, about their learning goals for students and what they think students learn through participation at their agencies.

Our qualitative data revealed a heavy emphasis by faculty and community partners on cultivating compassion and appreciation of difference in community-engaged teaching and research. Most faculty members reported that they wanted students to learn how to empathize with and navigate difference in a democratic society. They said they wanted students to "assume that others are doing their best, and to [develop] empathy" or to "focus on the similarities between people rather than the differences" and "to see there are things bigger than self." Indeed, cultivating these virtuous capacities in students is essential for a strong, functioning democracy in a modern and admittedly complex world.

Only a distinct few of the respondents focused their teaching and research goals on the development of concrete skills and critical thinking necessary to influence others or take public action. One faculty member said he tailored his course so that students could learn about "writing grants, petitioning government to change codes, and caring about society enough to do something!" Another faculty member, who focused on teaching about large-scale injustices, said, "I want students to understand how poor and minority communities are treated by health and social service agencies ... what solutions should be introduced, and who should be involved."

Through data analysis and coding of the survey responses, focus group transcripts, and archival data, we categorized responses into four broad categories: (a) community understanding and awareness, (b) building community capacities and solving problems, (c) a critical study of power or social justice, and (d) intercultural awareness and skills.

The most often cited student learning goal (28\%) was community understanding and awareness. More specifically, in this category faculty mentioned their focus on helping students to understand the value of public education, making students aware of how they can use their skills and knowledge to contribute to the community at large, and connecting classroom knowledge to world events.

One faculty member stated what many echoed, namely that teaching is simply better when it embraces community engagement:

I feel more energized in the teaching, and my research has gained a new focus. I routinely get feedback that the community organizations appreciate the student volunteers ... I think the community engagement is beneficial for all.

Community members and faculty both noted the brokering of relationships between members of the partnerships as vital to deepening the commitment to continuing the work.

Nineteen percent of responses indicated that building community capacities and solving problems was at the core of the instructional experience. Faculty reported that they designed their courses to address social problems, assess strengths and weaknesses in the community, strengthen community literacy, encourage creativity and self-expression, and facilitate communities to engage in public decision making.

An additional $19 \%$ of responses noted social justice or goals relating to the critical study of power as necessary student-learning outcomes. Here, faculty goals included exposing students to systems of power and oppression, discussing rights and how to acquire equal access to resources, and learning the routes of social change through institutional channels and grassroots initiatives. Interestingly, community members likewise agreed that exposing students to discussions of power and social change were vital, but they did not feel it was their "role" to provide that instruction, as if doing so unwisely entered contentious territory. One community member said, "We're just happy to have students here providing needed service to our clients."

The goal of increasing intercultural awareness and skills was cited in $15 \%$ of responses. Faculty reported that their teaching was designed, in part, to help students develop relationships across difference 
while expanding worldviews, learning cross-cultural communication, and developing an awareness of the cultural richness within the classroom as well as in the community.

Finally, and of concern to us, nearly one in five survey respondents, or $19 \%$ of the individuals who self-identified as community-engaged scholars, did not provide a response to the question regarding civic learning or democratic goals in their teaching. This survey question prompted one respondent to answer simply with a "?", possibly indicating a basic lack of understanding or, worse, suggesting the question was irrelevant. This discovery suggested strongly that faculty members need further education on the importance of civic learning and democratic engagement, and instruction or training in how to encourage development of these skills through their teaching.

\section{Institutional Support Can Bolster Civic-Engagement Scholarship}

Although acceptance of and support for civic engagement at colleges and universities are on the rise, "implementing, funding, and rewarding professional development ... remains a significant challenge for higher education institutions" (Jameson, Clayton, Jaeger, \& Bringle, 2012, p. 40). Blanchard et al. (2009) cited lack of faculty development opportunities, challenges in building portfolios for tenure and promotion, and lack of funding opportunities as barriers to civic-engaged scholarship. Although most academic institutions provide support and training in teaching and research, fewer offer professional development opportunities for community-based or democratically engaged scholarship (Jordan et al., 2012).

The top four resources this study's participants identified as necessary to enhance campuscommunity partnership activity and personal productivity were, in order of priority: additional financial streams; campus leadership in promoting program visibility; greater emphasis on integrating civic learning and democratic engagement into undergraduate student activities and graduate education; and, rewards and recognition of civic engagement as important scholarly work. Additionally, faculty members argued that for civic-engagement activity to flourish, all partners - faculty, community, and studentsneeded access to additional resources.

\section{It's About the Money, and It's Not About the Money; It's About Visibility, Too}

Having additional financial resources by way of internal and external grants was most often cited by participants, with $50 \%$ indicating that money would help pay for fees associated with attending civicengagement conferences, support graduate student assistants, and help defray costs associated with professional development in this area. Though disciplinary conference presentations are accepted as a required job duty for scholars that is supported in full or part by university resources, participants indicated that funds for service-learning and/or civic-engagement conferences are not plentiful and that attendance at these scholarly events is often regarded as "additional" rather than a required professional activity.

Almost as many study participants, $42 \%$, indicated the need for non-monetary resources, such as smaller class sizes, additional staff support, and increased opportunities for interaction among departments. These, participants said, are features of a healthy institution that wants to promote campuscommunity partnerships. Faculty also supported the idea that community members should accrue university benefits such as library privileges and free parking on campus.

Faculty also expressed the need for greater visibility of civic-engagement activity on campus. They conveyed the importance of valuing community-engaged "products" in addition to scholarly journal articles to build the momentum of valuing civic engagement.

It is worth noting that more than $80 \%$ of the study participants indicated that institutional support for their work was good or great, with only 19\% saying they received little or no support. Not surprisingly, faculty reported that in some departments traditional products of scholarship continued to be privileged, and, in the worst cases, their community-engaged research was relegated to the "service" category of tenure and promotion dossiers. Faculty agreed that consistent and vocal support from the institution's leadership would offer the best opportunity for civic-engagement activity to grow and sustain. 


\section{More Civic Learning and Democratic Engagement Activities for Students}

If civic engagement is to take root in campus life, colleges and universities much invest more time and energy in securing speakers and creating programs that inspire students to do meaningful work in the community. That was the sentiment expressed by $27 \%$ of the study participants. To that end, faculty members suggested that the university should offer students structured opportunities to earn certificates, graduate degrees, and other forms of concrete recognition for their civic-engagement work.

More concrete was the faculty call for transportation for students to get to community locations where they provide service during the semester. Though the city in which the university is located offers public bus transportation for student travel, the city's sparse routes and infrequent schedule make that a challenging option. The cost of private transportation, via rideshares or taxis, is cost-prohibitive for most of the campus' student population.

Finally, the faculty reported that students at this urban university often cite competing demands from work, school, and family as deterrents to what inevitably is more time-intensive civic-engagement activity. It is not uncommon, for instance, for a student to work 30 to 40 hours per week, attend school full time, and tend personally to family members with health issues. Students at this institution are often first-generation college attendees without the same at-home support structures in place that are more often seen in families with generations of college graduates.

\section{Rewards and Recognition for Faculty Doing Civic-Engagement Work}

The scholars in this study reported that they were proud of their accomplishments, yet only some of their scholarship products had been recognized formally. That is, conventional products, such as conference papers and posters, were well recognized, while other products such as community reports, contracted evaluations, and needs-assessment surveys were mentioned as key indicators of strong faculty productivity but not always recognized as such through on-campus peer evaluations. Faculty participants in the study also pointed to the value and necessity of writing grants for organizations (rather than grants applied for through university channels) and developing creative materials, including design products, films, and public tours, as essential to advancing community-engaged scholarship - initiative undertaken without the guarantee of university reward.

Faculty members indicated that, ideally, when their work contributes both to scholarly advancement and community impact, everyone wins. One faculty member reported that the evaluation she completed for a nonprofit was both published in an academic journal and used as a basis for securing additional funding for the nonprofit to study Alzheimer's.

From the faculty perspective, for community-based scholarship products to support underresourced communities, much time is needed to initially build and then deepen partnerships while at the same time planning so that student learning outcomes can be advanced and benefits to the community accrued. The potential for engaging in such high-impact activities is a strong motivator for faculty to perform the admittedly time-consuming work. Two faculty members specifically noted successes that kept them working in the community. One said, "The greatest effect of this project was systemic change" that fundamentally transformed how poverty was addressed in the community. Another explained that what was most rewarding for her was "being part of a process for developing new financial and leadership resources to a very discouraged and distrusting low-income community. I can visit the neighborhood and see a dramatic difference today."

Of note in faculty members' responses was the nearly normalized exhaustion ensuing from such civic work. Many faculty members cited that they must do twice the work to get sufficient academic recognition. They reported needing to first create products for the community and then produce similarly informed but very differently written scholarly articles. For one female faculty member, the challenge was particularly difficult since she conducted her research with low-income mothers. She said:

We work our schedule and interviews around the moms' needs so that we cause as little interference as possible. This often means long days, unusual hours, and many a weekend 
interviews. Sometimes you can feel bogged down from the schedule and feel required to put personal things aside in order to get the job done. It has been tough for me.

Not all faculty agree, however. One male faculty member of an older age cohort offered, "A different way to frame this is to say we basically have to show that our work matters. We have to prove that what we have done has made an impact on the community" as a new form of external review. Another faculty member suggested that more work was required to counter the campus narrative that community-engaged work is less rigorous than traditional forms. She suggested:

Within this university's culture there has to be more systemic and strategic efforts made to lift up ... the track of community engagement ... Educate them about how, and what are the indicators of importance and validity.

Another participant noted, with agreement from others in his focus group, that if the university wants to be a research institution, then all forms of scholarship should be valued. He explained:

We all have to fight the dominant narrative here that scholarship is [only] about enlightening the mind ... Older professors have an outdated view of what service and community engagement is. They think it's serving soup at a soup kitchen. They are holding the younger professors back ... We have 141 faculty members [in our unit] and 117 of them are engaged with or for agencies of one kind or another. But the narrative is controlled by $13 \%$ of the people that this stuff isn't really scholarship.

There has been progress at this university in recognizing via institutional channels, including promotion and tenure revisions, grant awards, and strategic planning. However, the faculty participants pointed out that until community-based scholarship is recognized fully-by well-informed decision makers and within the broader institutional culture - their civic-engagement activity will continue to be undertaken with some professional risks.

Similarly, faculty indicated that grant seeking and funding requirements are problematic for them. They reported that most sources of funding for civic engagement do not include opportunities to request indirect costs, those fees designed to support university research operations, and thus the faculty are torn between serving community partners and responding to university requirements. As one faculty member said:

Because of all the structural changes in U.S. higher education, with all the cutbacks, foundations haven't yet quite internalized all of that. So, they get irritated when projects and proposals come from faculty members seeking indirect costs to support what really the university should be supporting anyway, like graduate student time or faculty release time, things like that ... but the university pressures faculty to get precisely those line items, so we as faculty become sort of steered away from applying for foundation money because it doesn't come with NIH-style overheads. We're caught between all of these forces.

Another faculty member cited an additional pressure connected to grant seeking: "Planning and timing can be a problem. The community is here now, but grants often take a long time to plan and apply for." In sum, faculty found grant writing necessary but time consuming, without assurances that the university would value the work absent the ability to collect indirect costs. At the same time, community members may get frustrated with the faculty member's competing pressures surrounding grant activity.

\section{Recommendations to Enhance Thick Conceptions of Civic Engagement}

As suggested by the study participants' responses, a growing number of faculty members want to see their teaching and research efforts take hold in local communities in order to advance the public good. These faculty represent a wide range of disciplines, from history, biology, and public health to interior design, communication, and film. Though contributing in very different ways, more, not fewer, faculty are making connections, establishing partnerships, and sharing university resources in their communities. That movement, we think, bodes well for advancing the public mission of higher education to improve the condition of life for communities near and far. 
To tap into this momentum and build upon the successes already in place, several institutional ways of operating could benefit from both subtle and dramatic changes. In reflecting upon what faculty reported in this study, it is clear that a sustained focus on civic engagement is destined to always be a project in process. With that in mind, the following recommendations are offered as next steps in advancing civic learning and democratic engagement.

First, if the goal of civic learning and democratic engagement in higher education is to build upon and expand students' impact in the community, then student learning goals likewise need to be deepened. We found in this study that most faculty-determined goals for student learning were shallow or light, particularly with regard to engaging the political dimensions of community work. Indeed most learning goals reported were skewed toward empathy and away from political involvement or efforts that could lead to meaningful social change.

Thus, while students can participate in community affairs, their impact will be intensified through additional classroom instruction on how local political systems and local decision-making operate. Before that can begin, instruction with faculty around understanding political processes is necessary (BlochSchulman \& Jovanovic, 2010).

We recognize that one reason student learning goals may not be robust is that assessment measures effectively discourage goals that cannot be measured easily. Faculty may rightly be reticent to publish student learning goals on their syllabi that target transformative change-even if doing so is consistent with the mission of higher education-because accompanying assessment could be challenging or impossible.

Second, if institutions truly want to advance their democratic mission through faculty efforts, then more and greater rewards must be provided for teaching and research and embedded in decisions made by research funding committees, faculty evaluation committees, curriculum guidelines, and promotion and tenure decisions. As we found, even when policies are introduced to specifically recognize this work, actual change can be slow, incremental, and subject to backsliding.

Our research revealed that only half of the faculty survey respondents reported feeling supported by the institution in their community-engaged scholarship. They identified lack of validation and resources, as well as the increased personal time required to develop and sustain community partnerships as barriers to civic and democratic engagement.

Thus, community members must be enlisted as the allies they are in advocating for institutional supports and change in higher education. Community members routinely communicate loudly and clearly that faculty and student involvement in their projects catapults the impact of limited community funds and resources. However, college administrators, department chairs, and other faculty may not hear or appreciate the value of those comments. Communication, therefore, needs to be elevated to recognize that societal challenges require both community action and academic support. Setting aside funds specifically for community-engaged research, support, and student involvement is admittedly only one step in communicating the value of this form of scholarship, but it is perhaps the most important one to actualize institutional support. With that in place, faculty engaged with grassroots community organizers, nonprofit organizations, or start-up cooperatives, for example, can leverage the institutional funding to benefit the community and inspire on-campus culture shifts.

Third, since undergraduate and graduate research assistance in civic-engagement activity has proven its value (Kilgo, Sheets, \& Pascarella, 2015; Lopato, 2010), then institutions should leverage that resource through proactive programs to connect more faculty and students. Colleges and universities will increase their ability to partner in community initiatives by investing in mentoring practices to support students in connecting their passions for social justice and community building with academic rigor.

\section{Conclusion}

The current economic climate and public view of higher education, coupled with antiquated norms about what is valued within higher education, produce tensions around the real, not merely espoused, value of civic engagement. The neoliberal environment in which higher education operates 
increasingly treats education as a private right designed for job creation rather than as a public good for nurturing democratic thinking and action (Purpel, 1999). Further, many of the current metrics that determine funding and recognition stem from economic, not civic responsibility, indicators: retention, four- and six-year graduation rates, online education credit hours, Pell grant recipients, and degree efficiency (Giles, 2012; Poulos et al., 2015). Just as metrics warrant review, so do grant requirements and teaching responsibilities.

Some faculty become "the targets of a sustained attack on academic freedom" (Jovanovic, 2017, p. 331) when questions arise over how their work for the common good will be regarded among distinct, often incongruent discourses surrounding the use and implementation of civic-engagement programs. As one faculty member in our study said:

I am quite disillusioned with federal funding mechanisms, which really are not geared toward understanding and addressing important community concerns. I am disillusioned as well with the "culture of science" and the petty ways that academia measures its impact-usually measured as impact on other scholars.

Our research demonstrates that more conversations are needed amidst a changing political climate about what faculty should do, what kind of support they can expect to receive, and how they can work together to change the rules that govern their performance. These conversations will be contentious to be sure but critical for ensuring the rightful place of higher education in society. As Jovanovic (2017) wrote:

Education and democracy are intimately connected. You cannot have a robust democracy without an educated, critical thinking populace. That is where faculty come in, of course! Their duty is to educate students to live in this society and at the same time to question the injustices that persist. (p. 331)

Democratic engagement is a means for combating ignorance and apathy. Yet, the "dominant epistemology of the academy runs counter to the civic engagement agenda" (Saltmarsh et al., 2009, p. 5). Ellison and Eatman (2008) offered a similar refrain in their resource guide to promotion and tenure: Even such normally sympathetic fields as policy studies and social sciences more often tend to discourage junior faculty members from collaborative work that is interdisciplinary and publicly engaged. How many times have we heard, "You'd better wait until you get tenure before you do that"? We brag about the fabulous work of our engaged faculty—but can we get them promoted? (p. iii)

Indeed, the faculty who participated in our focus groups expressed these same concerns. Even with updated tenure and promotion guidelines in place at the institution, the culture in some departments and disciplines was strong in its resistance to any change. Thus, one faculty member summarized the situation this way:

So there's still a lot of politics that have not yet been worked out. And for pre-tenure people it's a very dangerous track to take at this time. I've cleared the tenure hurdle, but if I'm working from associate to full I again have to negotiate how to frame that, and I will have to.

When faculty members have their civic-engagement scholarship reclassified in tenure documents from research to service, we have to ask, How can policies drive a culture change whereby community-based research and democratic engagement are valued as essential to higher education?

If faculty and administrators cannot reduce the mounting fears and tensions in higher education, we worry that faculty will respond in adverse ways. They may hide, for instance, rather than share news of their strong civic work in campus meetings where some colleagues do not recognize its value as a valid form of scholarship and in public venues where challenges to the role of higher education are mounting (see Giles, 2012; Keene \& Reiff, 2012).

Perhaps not surprising, we found that not only faculty struggled with politics and pressures related to civic engagement. Community partners, too, expressed trepidation about speaking of political matters with students, with many of them facing the same neoliberal policies promoting efficiency over human well-being to which higher education is increasingly beholden. Community partners require reassurance that they can and should speak with students about how to work with or confront elected 
officials, attend meetings to attest to the value and challenges of nonprofits, and draft resolutions for local policy changes.

It may seem daunting or even unwise to think about moving from thin to thick conceptions of civic engagement. However, standing in the shadows of uncertainty and fear will not bring about needed changes in a society struggling to hold onto its democratic foundations. It is encouraging that the rhetoric of civic engagement is strong on campuses. This study aimed to move that rhetoric toward more action by proposing ways in which disciplinary expertise can more deeply align with solutions to public problems. This research further demonstrates the need for more democratic engagement instruction for faculty, students, and community partners. Moving to thick conceptions of civic engagement is perhaps the surest way to fulfill the promise of higher education institutions to be agents of change that promote a just vision through persistence, critical thinking, knowledge, and courage.

\section{Author Note}

Spoma Jovanovic, Department of Communication Studies, University of North Carolina at Greensboro; Kristin Moretto, Brooks College of Interdisciplinary Studies, Grand Valley State University; Kathleen Edwards, Educational Leadership and Cultural Foundations, University of North Carolina at Greensboro.

Correspondence regarding this article should be addressed to Spoma Jovanovic, Professor, Department of Communication Studies, University of North Carolina at Greensboro, 108 Ferguson Building, P.O. Box 26170, Greensboro, NC 27402. Phone: (336) 334-5297. E-mail: s jovano@uncg.edu

\section{References}

Adler, R. P., \& Goggin, J. (2005). What do we mean by "civic engagement"? Journal of Transformative Education, 3(3), 236-253.

Anderson, R., Baxter, L. A., \& Cissna, K. N. (2004). Dialogue: Theorizing difference in communication studies. Thousand Oaks, CA: Sage.

Ayers, W. (2004). Teaching toward freedom: Moral commitment and ethical action in the classroom. Boston: Beacon Press.

Barber, B. R. (1984). Strong democracy: Participatory politics for a new age. Oakland: University of California Press.

Blanchard, L. W., Hanssmann, C., Strauss, R. P., Belliard, J. C., Krichbaum, K., Waters, E., \& Seifer, S. (2009). Models for faculty development: What does it take to be a community-engaged scholar? Metropolitan Universities, 20(2), 47-65.

Bloch-Schulman, S., \& Jovanovic, S. (2010). Who's afraid of politics? On the need to teach political engagement. Journal of Higher Education Outreach and Engagement, 14(1), 83-100.

Boyatzis, R. E. (1998). Thematic analysis and code development: Transforming qualitative information. Thousand Oaks, CA: Sage.

Boyle-Baise, M. (2002). Multicultural service learning: Educating teachers in diverse communities. New York: Teachers College Press.

Boyte, H. C., \& Scarnati, B. (2014). Transforming higher education in a larger context: The civic politics of public work. In P. Levine \& K. Soltan (Eds.), Civic studies: Approaches to the emerging field (pp. 77-89). Washington, DC: Bringing Theory to Practice.

Bringle, R. G., \& Hatcher, J. A. (1995). A service learning curriculum for faculty. Michigan Journal of Community Service Learning, 2, 112-122.

Chemerinsky, E., \& Gillman, H. (2017). Free speech on campus. New Haven, CT: Yale University Press.

Collaborative on Academic Careers in Higher Education. (2012). COACHE faculty job satisfaction survey. Provost's report. University of North Carolina at Greensboro. Cambridge, MA: Author. 
Retrieved from https://ire.uncg.edu/surveys/coache/ coache11_report.pdf

Cortes, E. (2010). Quality education is a civil right. In T. Perry, R. Moses, J. Wynne, E. Cortes, \& L. Delpit (Eds.), Quality education as a constitutional right (pp. 93-105). Boston: Beacon Press.

Creswell, J. W. (2003). Research design: Qualitative, quantitative, and mixed methods approaches (2nd ed.). Thousand Oaks, CA: Sage.

Creswell, J. W. (2007). Qualitative inquiry and research design: Choosing among five approaches (2nd ed.). Thousand Oaks, CA: Sage.

Della Carpini, M. X. (2004). Mediating democratic engagement: The impact of communications on citizens' involvement in public life. In L. Kaid (Ed.), Handbook of political communication research (pp. 395-434). Mahwah, NJ: Lawrence Erlbaum.

Diaz, A., \& Perrault, R. (2010). Sustained dialogue and civic life: Post-college impacts. Michigan Journal of Community Service Learning 17(1), 32-43.

Duerringer, C. M. (2013). "They'd better hope for a lot of free parking": Using Monopoly to teach about classical liberalism, marginalization, and restorative justice, Communication Teacher, 27(1), 1115.

Ehrlich, T. (2000). Civic responsibility and higher education. Westport, CT: Oryx Press.

Ellison, J., \& Eatman, T. K. (2008). Scholarship in public: Knowledge creation and tenure policy in the engaged university. Syracuse, NY: Imagining America. Retrieved from http://imaginingamerica.org/wp-content/uploads/2015/07/ ScholarshipinPublicKnowledge.pdf

Gastil, J., \& Levine, P. (2005). The deliberative democracy handbook: Strategies for effective civic engagement in the twenty-first century. San Francisco: Jossey-Bass.

Gay, G. (2015). Authentic teaching is venturing into uncertainty. In S. Totten (Ed.), The importance of teaching social issues: Our pedagogical creeds (pp. 23-32). New York: Routledge.

Giles, H. (2012). Negotiating the boundary between the academy and the community. In D. Butin \& S. Seider (Eds.), The engaged campus: Certificates, minors, and majors as the new community engagement (pp. 49-68). New York: Palgrave Macmillan.

Giroux, H. A. (2012). Twilight of the social: Resurgent publics in the age of disposability. Boulder, CO: Paradigm.

Giroux, H. A. (2017, October 20). Rethinking higher education in a time of tyranny. Retrieved from http://billmoyers.com/story/rethinking-higher-education-in-a-time-of-tyranny/

Hatch, J. A. (2002). Doing qualitative research in educational settings. Albany: State University of New York Press.

Hess, D. E., \& McAvoy, P. (2015). The political classroom: Evidence and ethics in democratic education. New York: Routledge.

hooks, b. (2003). Teaching community: A pedagogy of hope. New York: Routledge.

Jameson, J. K., Clayton, P. H., Jaeger, A. J., \& Bringle, R. G. (2012). Investigating faculty learning in the context of community-engaged scholarship. Michigan Journal of Community Service Learning, $18(2), 40-55$.

Jordan, C., Jones-Webb, R., Cook, N., Dubrow, G., Mendenhall, T. J., \& Doherty, W. J. (2012). Competency-based faculty development in community-engaged scholarship: A diffusion of innovation approach. Journal of Higher Education Outreach and Engagement, 16(1), 65-95.

Jovanovic, S. (2017). Speaking back to the neoliberal agenda for higher education. Cultural Studies, Critical Methodologies, 17(4), 327-332.

June, A. W. (2014, July 25). The uncertain future of academic work. Chronicle of Higher Education, $L X$ (42), A10 \& A12.

Keene, A. S., \& Reiff, J. (2012). Contending with political and cultural campus challenges. In D. Butin \& S. Seider (Eds.), The engaged campus: Certificates, minors, and majors as the new community engagement (pp. 69-88). New York: Palgrave Macmillan. 
Kilgo, C. A., Sheets, J. E. E., \& Pascarella, E. T. (2015). The link between high-impact practices and student learning: Some longitudinal evidence. Higher Education, 69(4), 509-525.

Lopato, D. (2010). Undergraduate research as a high-impact student experience. Peer Review, 12(2), $27-$ 30.

Musil, C. M. (2012). A "national call to action" from the National Task Force on Civic Learning and Democratic Engagement. In D. Harward (Ed.), Civic provocations (pp. 69-74). Washington, DC: Bringing Theory to Practice.

National Task Force on Civic Learning and Democratic Engagement. (2012). A crucible moment: College learning and democracy's future. Washington, DC: Association of American Colleges and Universities.

Overton, B., Pasque, P. A., \& Burkhardt, J. C. (Eds.) (2017). Engaged research and practice: Higher education and the pursuit of the public good. Sterling, VA: Stylus.

Perry, D., \& Menendez, C. (2010). Urban universities as anchor institutions: A report of national data and survey findings. Washington, DC: Coalition of Urban Serving Universities.

Post, M. A., Ward, E., Longo, N. V., \& Saltmarsh, J. (Eds.). (2016). Publicly engaged scholars: NextGeneration engagement and the future of higher education. Sterling, VA: Stylus.

Poulos, C. N., Hamilton, C., Jovanovic, S., \& Moretto, K. (2015). Our work is not done: Advancing democratic engagement as purpose and product of higher education. Journal for Higher Education and Community Engagement, 7, 34-46.

Purpel, D. E. (1999). Moral outrage in education. New York: Peter Lang.

Saltmarsh, J., Hartley, M., \& Clayton, P. H. (2009). Democratic engagement white paper. Boston: New England Resource Center for Higher Education.

Snyder- Hall, C. (2012). Beyond the ivory tower: The civic aspirations of faculty. Connections, 34-36. Stoecker, R. (2016). Liberating service learning and the rest of higher education civic engagement. Philadelphia, PA: Temple University Press.

Wang, H. L. (2017, July 3). Amid "devastating” progress nationally, Black Lives Matter engages local causes. All things considered. Washington, DC: National Public Radio. Retrieved from https://www.npr.org/templates/transcript/transcript.php?storyId=535076154 